\title{
Migrating techniques, multiplying diagnoses: the contribution of Argentina and Brazil to early 'detection policy' in cenvical cancer*
}

\author{
Técnicas que migram, \\ diagnósticos que se
} multiplicam: a contribuição de Argentina e Brasil para a política de 'detecção precoce' do câncer cervical

ERASO, Yolanda. Migrating techniques, multiplying diagnoses: the

contribution of Argentina and Brazil to early detection policy in cervical cancer. História, Ciências, Saúde Manguinhos, Rio de Janeiro, v.17, supl.1, July 2010, p.33-51.

\section{Abstract}

This article on the early detection of cervical cancer focuses on the development of two leading diagnostic techniques - colposcopy and the Pap smear test - and their histories in Argentina and Brazil. It explores how diagnostic tools were transferred between Europe and the Americas, while examining the intersection of cultural and medical aspects and the processes of adaptation and resignification in the receiving countries. Colposcopy received little attention in the main Western medical centers until South American countries reasserted its significance in the 1950 s. 'Peripheral' centers played a central role in early detection policies and the combined uses of these methods gave rise to a new stage of 'cumulative confidence' in cervical cancer diagnosis and screening.

Keywords: transnational history: colposcopy; Pap test; cervical cancer; diagnosis.

Resumo

Esteartigo trata da detecção precoce do câncer cervical. Coloca em evidência as duas principais técnicas diagnósticas, a col poscopia eo teste de Papanicolau, e mostra suas trajetórias no Brasil ena Argentina. Analisa o modo como se deu a transferência de métodos diagnósticos entre a Europa eas Américas, procurando perceber a interseção de aspectos médicos e culturais eainda os processos deadaptação e ressignificação nos países queacol heram as novas técnicas. A col poscopia recebeu pouca atenção nos principais centros médicos ocidentais atéos países sul-americanos validarem sua importância nos anos 1950. Centros 'periféricos' desempenharam papel crucial nas políticas de detecção precoce, eo uso combinado desses métodos deu lugar a novo estádio de 'confiança cumulativa' no examee diagnóstico do câncer cervical.

Palavras-chave: história transnacional; col poscopia; testede Papanicolau; câncer cervical; diagnóstico. 
his article analyzes the history of the two main methods of cervical cancer detection

- colposcopy and the Pap smear test - and how their histories in Argentina and

Brazil contributed to redefining cancer categorization and diagnosis around the world. The study is firmly rooted in a transnational perspective and uses the notion of transfer to interpret the migration of medical ideas and technologies across national borders. Exploring broader aspects of social history, the study of socio-cultural interactions between countries - namely, comparative history, transfert culturel, and, more recently, histoire croisée - has attracted a wide range of scholarship for over twenty years (Werner, Zimmermann, 2006). However, it has only been recently that transnational exchanges have interested historians of medicine and science. The idea that Latin American medicine and healthcare have been heavily influenced by European and American ideas and models is almost a selfevident idea for historians, yet the actual, complex process by which this widely recognized influence has taken place in concrete cases has been underestimated. Likewise, the influence of foreign ideas on the histories of the main Western medical systems has rarely been addressed, in an overtly nation-centered perspective.

If we focus on a disease like cancer, transnationalism features largely in its history, despite countries' efforts to maintain an association between 'medical innovations' and 'national histories.' This paper proposes that the history of the diagnosis of cervical cancer could be read as a story of academic exchanges, migrating peoples, personal contacts, and nationalistic zeal. Specifically, I argue that its history can be better understood if attention is drawn to synchronic developments in several countries at a given moment.

Over the past few decades, most preventive campaigns for the early detection of cervical cancer in Argentina and Brazil have relied on the use of colposcopies and Pap tests as 'routine procedures,' while in the United States and in European countries, colposcopic examination has been reserved as a follow-up to abnormal Pap tests. Invented by German gynecologist and pathologist Hans Hinselmann in 1925, the technique of colposcopy received little attention in the main Western medical centers until the 1950s. However, reliance on his technique did spread to Argentina and Brazil, where it is said to have been saved from oblivion during World War II. In this sense, the article examines the intersection of a series of elements in the above-mentioned countries in order to explore how these diagnostic tools were transferred. It first focuses on the cultural and medical settings where the process of transfer took place, with special focus on the intermediary channels inherent to gynecology (institutions, congresses, and publications). Second, it examines the development of colposcopy in a context where the diagnosis of cancer at an early stage became a widely accepted notion among specialists. This then leads to an analysis of the 'mediators,' or agents and individuals who, according to Christophe Charle (2004, p.199200), play three distinctive roles: importing and exporting knowledge and methods; transmitting such knowledge by setting up schools, learned societies, and journals; and, finally, adapting transferred knowledge to the local culture.

After analyzing the introduction of the Pap test in the 1940s, a general discussion on the reception of both methods in Argentina and Brazil follows. It pays particular attention to implementation and adaptation as well as to the innovations introduced in gynecological clinics in the 1950s. As the literature on cultural transfer suggests, "a successful transfer 
often implies changes in the original practice that will adapt it to its new environment, so that its foreign origin is no longer visible" (Te Velde, 2005, p.208). Significantly, this could imply perceptible changes such as linguistic ones (i.e., the translation of terms or the introduction of new terminology) or, more importantly, changes observable at the level of practices. I argue that meaningful changes in cancer diagnosis were perceived as a result of the transferred diagnostic tools, whose implications went beyond the borders of the countries analyzed.

\section{Transnational academic exchanges and international networks: the case of obstetrics and gynecology}

International academic exchanges have not occurred contingently but rather through a range of channels that have made contacts possible, namely: academic travels to foreign institutions, the circulation of specialized publications, exchange programs for international students, the organization of international conferences, and the dissemination of knowledge by international organizations (Charle et al., 2004, p.13). In the medical field, South American students have gone abroad to complete specialized medical training. In the case of obstetrics and gynecology, students have traveled to different places during different periods. Since the end of the nineteenth century, France and Germany were the main medical schools that drew students in the Western world. France became particularly renowned in the area of obstetrics and puericulture during the first decades of the twentieth century. For those specializing in gynecological cancer, a visit to the Curie Institute to gain familiarity with the latest techniques developed in radiotherapy and radium also became mandatory.

Although French medicine continued to influence Latin American medical education, the 1930s witnessed an increasing re-engagement with German medicine, especially in the areas of gynecology and surgery. This process was facilitated through the creation of institutions on both sides of the Atlantic. The Argentinean Committee of University Information was set up in Berlin in 1931 to assist students in gaining academic experience at German universities. Between 1935 and 1938, within the Third Reich's health system, it was the Deutsch-Ibero-Amerikanische Ärzte-Akademie (German-Iberoamerican Medical Academy) that best promoted cooperation, exchange, and education for Latin American doctors. The Academy's work was very intense, as demonstrated by its cycles of conferences and hospital training, its financial aid for doctors (grants and scholarships), and its action as an intermediary when doctors wanted to acquire precision instruments, one of Germany's main export industries (Reggiani, 2005). Between 1936 and 1938, hundreds of Latin American doctors visited Germany under the auspices of the Academy and, in the case of Brazil and Argentina, the sponsorship of the Bayer pharmaceutical company (Sá et al., 2009). The advent of National Socialism thus seems to have reinforced the channels for disseminating German medicine in South America, at least until the start of World War II.

The 1940s and 1950s saw a gradual orientation towards United States medicine in areas such as endocrinology, cytology, surgery, and chemotherapy. The Rockefeller Foundation was instrumental through its well-funded system of grant schemes, which financed Brazilian 
and Argentinean doctors working to complete their specialization studies at prestigious hospitals and institutes. Although the Foundation had maintained supporting programs and fellowships in public health and epidemic control and eradication since its inception in 1913, in the 1940s its policy shifted to supporting scientific education and focusing on the work of recognized researchers and institutes in biomedical investigation (Cueto, 1994, p.128-131). In 1941, an international health division office for Latin America was set up in Buenos Aires, although the main support given to the country was almost exclusively concentrated in physiology, an investment that subsequently helped to develop the field in Brazil. Towards the end of 1941, Brazil rejected its former neutral stance towards the Axis countries, putting the circulation of German specialists and instruments on hold. As Alexandre Ribeiro de Carval ho has stated, this signaled "the end of German technical predominance in cancer surgery and radiotherapy in Brazil, and the start of the prevalence of American technology in the newly created sub-field of Brazilian medicine". (Ribeiro de Carvalho, 2006, p.92).

During the 1940s, Latin American networks in obstetrics and gynecology also served as important vehicles for the transfer of medical ideas, as we will see throughout this paper. With World War II forcing isolation from European centers, Latin American centers and doctors forged closer links among themselves. International congresses and conferences played a major role in the exchange of medical experiences but so too did the generation of networks and relationships that later resulted in further collaboration. International congresses in obstetrics and gynecology started to be celebrated with regularity from 1931 on, when Argentina organized its first national congress in both specialties, with the participation of South American specialists. In addition, held annually since 1940, the River Plate meetings originally organized by Uruguay and Argentina were attended by an increasing number of Latin American doctors. Moreover, the direct products of these congresses, like proceedings and special journal issues, were instrumental in transmitting the notion of a Latin American perspective in the specialty, a message that was made central to the journal Obstetricia y Ginecología Latino-Americanas when it first appeared in 1943. Towards the end of the decade, the Latin American Federation of Societies of Obstetrics and Gynecology (Federación Latino-americana de Sociedades de Obstetricia Y Ginecología, or Flasog) (1949) signaled the culmination of a long process of professional cohesion in the field. As we will see, this medical integration al so provided the context wherein diagnostic tools for the early detection of gynecological cancer circulated.

\section{Hinselmann and the visualization of precancerous lesions}

The first notions of precancerous lesions were reported in the late nineteenth century, when histological samples of atypical lesions were found adjacent to invasive cancers (Williams, 1888). By the early twentieth century, Dr. Hans Hinselmann (1884-1959) and others in Germany were conducting investigations on small thickened white patches in the mucosa of the cervix, named leukoplakia, but they soon encountered the difficulties posed by naked-eye examination. Hinselmann then developed an instrument for visual inspection of the cervix at a magnified scale. In 1925, he reported construction of the first 
colposcope, with the help of Leitz technicians. The device consisted of a fixed binocular instrument mounted on a tripod and equipped with a light source and a mirror to direct the light. Since then, a wide variety of improvements have been made to optimize the functioning and capabilities of the colposcope, many of which were introduced by the inventor himself. The magnified images showed Hinselmann that leukoplakia displayed different shapes and features, and he completed his analysis with the histological correlation of each image. He concluded that in most cases leukoplakia constituted small carcinomas.

With regard to so-called early cancers, wecan now say that col poscopy enables detection of considerably earlier cases. Even a tiny dot-liketumor should not escape detection. In principle we can detect lesions as small as one could care to think of (Hinsel mann, in Burghardt, 1998, p.4).

Until then, gynecologists could only detect visible tumors of the cervix of around $4 \mathrm{~cm}$, a size that indicated localized cancer (classified as stage I), that is, that the disease had not been spread beyond the uterine cervix. Even in such ideal cases, 5-year survival rates were not significantly high. Hinselmann also enhanced the colposcopic view of abnormal epithelium by staining the cervix with acetic acid, which turned abnormal cells white. By 1928, the technique was improved by a test invented by Schiller, in which the surface of the cervix was painted with an iodine solution to contrast the images of potential abnormal cells during colposcopic examination. Normal epithelium turns mahogany brown, while atypical (benign or malign) lesions appear unstained or white, in the latter case because the cells are deficient in glycogen, causing them to react differently.

In tandem with these improvements in visualization, Hinselmann developed terminology to describe the various lesions he observed with the colposcope. He drew attention to three detected images: leukoplakia, punctuation (which he called ground of leukoplakia), and Felderung, now known as mosaic leukoplakia. Histological study of these changes led him to classify the epithelium into two larger groups, "atypical or simply atypical" and "markedly atypical or cancerous," each of which corresponded to different matrixes or stages of tissue transformations. More important were the conclusions he drew from his detailed observations: "exceptionally with the naked eye but certainly with the colposcope, it is possible to detect epithelial changes which appear as leukoplakia and which in time may progress to carcinoma" (Hinselmann, in Burghardt, 1998, p.4).

The idea that the colposcope could detect the abnormal epithelium that would develop into cancer offered the potential of a major breakthrough as a population screening tool. Its general acceptance, however, was quite slow, especially during the interwar period when most European countries and the United States felt the technique required considerable training and expertise regarding the interpretation of images. Colposcopy was al so criticized for its complicated nomenclature and reliance on an expensive instrument. At the same time, there was no scarcity of opposition from pathologists, as they did not agree about the potential of abnormal cells to become true cancer, since many believed that cellular changes could take various courses: they could regress back to normal, they could remain static in their condition, or they could progress into invasive cancer. On the other hand, the morphological characteristics of precancerous cells were also the target of much 
contestation, as shown by the numerous classifications that followed down through the years. Ultimately, political circumstances also played an important role in the fate of colposcopy as a diagnostic tool. Although Hinselmann's involvement in cervical cancer experiments during the Nazi period was never proved, his collaborators - Eduard Wirths (a doctor at Auschwitz) and his brother Helmut (a colleague of Hinselmann) - were condemned for using "the colposcope to collect samples of cervical tissue from camp inmates, which were then sent back to Hamburg for examination by Hinselmann and Helmut" (Proctor, 2000, p.33). Hinselmann was, however, sentenced to three years in prison in 1946 by a British Military Government Court in Hamburg for the sterilization of six gypsies. During this time, only 'peripheral' centers like Switzerland, Austria, Brazil, and Argentina adopted colposcopy as a diagnostic technique.

\section{Argentina}

An emphasis on early diagnosis of cancer has dominated anticancer campaigns throughout the twentieth century around the world. Much of this emphasis has specifically targeted gynecological cancers, primarily because medical concern about women's cancer played an outstanding role in positioning the disease in the public domain, as historians have noted (M oscucci, 2005; Löwy, 2010; Bryder, 2008; Lerner, 2001). As the first statistics on cancer started to be reported in Argentina in the 1920s, uterine cancer stood out as the most significant cause of death among gynecological cancers, with cervical cancer itself responsible for 1,000 deaths per year. In 1926, it was estimated that only $10 \%$ of cervical cancers were readily operable, that is, circumscribed to the cervix and not spread to other parts, such as the vagina, annexes, or uterine body. This was grounded in the theory of cancer as a localized disease that started as a small tumor and then spread, metastasizing in other tissues and organs later in its course. Those with specific, localized cancers had better chances of still being alive five years later, which was the period of time internationally established to assess the efficacy of different treatments: A woman who underwent surgery and was alive five years later was considered cured and surgical treatment credited for the success. This led doctors and campaigners to promote the early detection of symptoms in the female population, encouraging them to seek medical advice promptly. The core message was "cancer is curable if treated early," "be aware of the first symptoms," "seek medical advice," "don't delay: it will be too late." Breast cancer topped the warning list, with recommendations that women not "worry about" "non-painful induration of the breast." However, cervical cancer was described as not displaying specific symptoms like lumps in its early stages, making diagnosis difficult and its propagation very fast. Symptoms such as abdominal pain, hemorrhages, or foul discharge only served to confirm the disease, as one doctor lamented, but "they were of little aid in terms of curability" (Giménez, 1926, p. 90). Without timely, clear symptoms, early detection was initially the responsibility more of doctors than women. Thus, at the end of the 1920s, gynecologists turned towards a group of pathologists who had started to describe the morphological characteristics of what they called "non-invasive" cancer or precancerous lesions. It was in this period that colposcopy found a favorable space for its inception in Argentina. 


\section{Colposcopy}

In 1928, Dr. Ahumada, then assistant at the Gynecologic Clinic at Buenos Aires University, introduced the first colposcope into clinical practice during a period of renovation and improvements introduced by the newly appointed head of the clinic, Dr. Julio Iribarne (Ahumada, 1935). At the Primer Congreso de Obstetricia y Ginecología in 1931, Ahumada highlighted the efforts in the early diagnosis of cancer in Germany (the country where he trained) and presented colposcopy as a leading method for the visualization of what he called the leukoplakia period (De la Vega, 1931, p.491).

Another important landmark in the broader use of colposcopy in Argentina and indeed in Latin America was publication of a detailed, fully-illustrated article on the technique by Dr. Roberto Gandolfo Herrera, published in the journal Revista Médica Latino-Americana in 1934. In it, he described Hinselmann's classification of colposcopic images and drew special attention to recognition of the 'pre-leukoplakia states' and their histological classification. He warned, "It is not enough to be behind the colposcope to do a colposcopy: it necessarily entails painstaking, lengthy practice that is only achieved through repetitive observations" (Gandolfo Herrera, 1934, p.852). Indeed, use of the colposcope as a technology implied the idea of the 'trained eye'; as he put it, "we need to accustom our eyes to seeing that which is observed." This implied, in turn, "trained judgment," which, as Daston and Galison havestated, defined the figure of the expert in twentieth-century science as someone "with a trained eye that could perceive patterns where the novice saw confusion" (Daston, Galison, p.328). I have suggested elsewhere that the paradigm of the 'trained eye' was crucial in making the gynecologist into a cancer expert, as his practiced eye with the colposcope enabled him to quickly read or interpret a portion of the cervix as normal or atypical, without resorting to the knowledge of other professionals (Eraso, 2009).

If the above-mentioned gynecologists contributed to the dissemination of thetechnique, it was Dr. Alfredo Jakob who became the first specialist and earned Argentinean colposcopy the recognition for which it is world famous today. Jakob trained with Hinselmann in Hamburg in 1932. On his return, he introduced the practice of colposcopy at the Buenos Aires Maternity Institute (Instituto de Maternidad de la Capital Federal). Trained as a gynecologist, Jakob was the son of a German neuropathologist who developed a worldrenowned laboratory for the histological study of the brain in Argentina. Jakob benefited from his father's knowledge of pathology and from the laboratory facilities at Argentina's Hospital Nacional de Alienadas, a female mental asylum, where he performed many of his histological studies on cervical cancer. In 1934, he was appointed to the recently opened Sardá Maternity Hospital (Maternidad Sardá), where he initiated colposcopic examinations of all women seen at outpatient consultations. He also offered training courses where many gynecologists from South America learned the technique. In 1939, he reported that one of his patients with an initial diagnosis of leukoplakia, who had follow-up biopsies for 2.5 years, eventually presented cervical cancer (Jakob, 1939). At a time of uncertainty and high mortality rates, this case might have served to convince gynecologists, first, that early stages of cancer were impossible to detect with the clinically unaided eye - as Jakob's colleagues failed in identifying the disease in the above-mentioned case - and, second, 
that abnormal epithelium resulted in cancer in a relatively short period of time. In any case, colposcopy, along with Hinselmann's classification of precancerous lesions, found enthusiastic supporters among gynecologists in Buenos Aires, who gradually adopted it as a reliable technique for early cancer detection.

A second phase in the history of the transfer of colposcopy technology took place in the 1950s and was characterized by Hinselmann's travels to South America. In 1951, Ahumada, then head of thegynecology clinic at BuenosAires University, invited Hinsel mann to offer students training courses in colposcopy. Hinselmann extended his visit for four months, during which time he attended conferences, gave practical demonstrations, and travelled tirelessly to the main clinics of Brazil, Argentina, and Uruguay. The former asymmetrical situation, where South American doctors trained at German clinics, had somehow been reversed. In the 1950s, it was Hinselmann's journey to South America and his numerous publications in Brazilian and Argentinean journals, where he communicated on improvements in the technique, that gained colposcopy the necessary international recognition denied it in post-World War II Europe and the United States. Finally, the direction of academic exchanges is also revealing, indicating how the older, undisputable European prominence in Latin American medicine was now a space to conquer, given American interests and endeavors in the area. In the specific case of cancer diagnostic tools, the Pap test was spreading rapidly, thanks to promotion by United States cancer agencies and to the financial support that South American doctors received to train with Papanicolaou in New York, as we will see later.

Invited to give a presentation at the Medical Circle in the Argentinean province of Córdoba, Hinselmann took the opportunity to challenge the United States for its "absolute ignorance in this science" [colposcopy] and pointed out "the lack of enough cases" to prove the utility of the Pap test in the diagnosis of precancerous lesions (Hinselmann, 1952a, p.14). He also mentioned that Papanicolaou did not respond to a letter he had sent, asking for information on this matter. Furthermore, he argued that a positive Pap test would lead to multiple biopsies, which could not demonstrate the existence of cancer if the tissue was extracted from the wrong place. More importantly, he questioned the new international classification of cervical cancer (1950), which incorporated the notion of "stage 0 cancer" to refer to the categories of "in situ cancer," "preinvasive cancer," or "superficial cancer." In all these cases, the word "cancer," Hinselmann rightly argued, presented an "evident contradiction," because cancer implies invasion; therefore, without invasion (preinvasion), there could be no cancer. He somehow prophetically warned, "The term 'cancer' should not be abused in this way; the consequences are unpredictable" (Hinselmann, 1952a, p.14). Indeed, one of the consequences was an increase in surgical activism. While the correlation between detected cell and tissue changes and clinical cancer remained controversial, prophylactic surgery gradually becamethemost common preventive measure to counteract the risk of cervical cancer.

It is revealing that some gynecologists in Argentina rejected the stage 0 notion and continued using Hinselmann's classification of matrices; thus, for example, "atypical epithelium III" was equivalent to stage 0 cancer. From the perspective of the process of transfer, I would argue that the 'translation' into Spanish of Hinselmann's key classificatory 
terms also became a way of appropriating the technique in receiving nations, not merely in its role of accessibility/communicational value but in the sense of professional recognition and expertise. The attention occasionally given to the use of these terms is revealing. For example, a report detailing colposcopic images in Argentina reads: "Felderung, recuadrado (Ahumada), enrejado (Jakob) o mosaico," where the first term is Hinselmann's original German name; the second and third terms are the translations used by the gynecologists named in parentheses; and the final word is the common, colloquial translation of the term in Spanish (Cerutti, 1952, p.181).

By the 1950s, the main gynecological clinics in Buenos Aires, along with a few others in the provinces (San Juan, Santa Fe), were practicing colposcopy, while many more gynecologists across the country knew of the technique and referred patients to centers that possessed the instrument. Colposcopy thus became the first screening method before the Pap smear test, as it was first performed on an asymptomatic population.

\section{The Pap smear test}

Exfoliative cytology as a cancer diagnostic tool was successfully introduced by zoologist Georges Papanicolaou in collaboration with Herbert Traut between 1941 and 1943, after overcoming the scientific community's initial indifference when Papanicolaou first presented his finding in 1928. The technique implied the microscopic examination of cells scraped from the cervix, previously fixed on a slide with the staining method. As Ilana Löwy has argued, the initial aim of the Pap test was diagnosis of invasive cancer, but it soon became "a screening test that detects potentially precancerous lesions and prevents cancer" (Löwy, 2009).

The strong support and promotion that the Pap test received in the United States during this period was the result of the reorganization of the American Cancer Society (ACS), which in 1945, equipped with an impressive budget, sought to encourage early intervention rather than preventive policies in cancer care. According to Casper and Clarke, despite the fact that the Pap test was not an accurate, fast, or cheap diagnostic tool, it "appealed to ACS leaders as a simple technique that could help fulfill their slogan without the need for elaborate or expensive new technologies - the right tool for the chosen job" (Casper, Clarke, 1998, p.261). With the support of the ACS, the Pap test was quickly disseminated around the world via international congresses, training programs, and large scale screening studies in the United States.

In Argentina, the smear test was introduced in 1946, after Dr. Isaac Schtirbu trained with Papanicolaou at Cornell Medical School in New York. He introduced the test at the Rawson Hospital gynecological center in Buenos Aires, one of the centers focused on cancer diagnosis in the 1930s. It is striking that despite having trained with Papanicolaou, Schtirbu's first reports to Argentinean doctors were quite cautious about the test's value as a diagnostic tool. Arguably, in Argentina the Pap smear test had arrived in a scenario dominated by colposcopy, unlike other countries. Schtirbu felt it was not possible to subject women to a routine examination that entailed "cruel interventions, biopsies, or curettage but it [was] possible to perform on all of them a simple colposcopic examination 
or vaginal smear, which is not upsetting or harmful to the patient" (Schtirbu, 1948, p.209). He emphasized presenting the Pap test as a diagnostic tool with a "presumptive" value, which needed to be "confirmed" by a biopsy, which in turn had to be performed under colposcopic examination (directed biopsy). Some years later, Hinselmann's presence in South America reinforced, among gynecologists, the idea of a necessary combination of diagnostic tools. As a result, in this region the Pap smear did not develop into a unique screening tool for cancer diagnosis nor did its use replace that of colposcopy, as we will see later.

Further improvements in the Pap test, notably the introduction of Ayre's spatula to scrape the cells, lent the technique renewed vigor, thanks also to the international promotion championed by its inventor. In 1955, Ayre accepted an invitation to participate at the Ninth Argentinean Congress of Obstetrics and Gynecology, an opportunity he enthusiastically used to visit Brazil as well. By then, Ayre was director of the Cancer Cytology Center in Miami, a privately funded center that received the support of the Washington Cancer Institute. His arrival at the Gynecology Institute (Instituto de Ginecologia) in Rio de Janeiro was preceded by the institute's celebration of the thirtieth anniversary of colposcopy. During his visit, Ayre struck Brazilian doctors as a man on a mission: he offered grants to train with him in Miami and invited doctors to attend the First PanAmerican Cancer Cytology Congress in 1957, an invitation that several specialists from both countries accepted.

While physicians were familiarizing themselves with the Pap smear test, comparisons between the two diagnostic techniques soon came under scrutiny. Jakob and the pathologist Dr. Dardo Escalante published a book with a compilation of results and experiences with colposcopy covering 20 years of practice at the Sardá Maternity Hospital, entitled El cáncer preinvasor del cuello uterino (Preinvasive cancer of the cervix). An overview of the advantages that Jakob claimed for colposcopy gives us insight into some of the debates prompted by introduction of the Pap test within the medical practice: a) it was argued that a positive Pap test would simply not indicate where to extract sample tissue for a biopsy; b) a positive test meant that more examinations would need to be performed before a final diagnosis could be made (this could take weeks), while with colposcopy, once the lesion had been identified visually, a sample could betaken immediately, with the patient very rarely needing to be re-examined; c) the Pap test meant organizing new laboratory facilities and staff, in turn requiring more resources, while, according to Jakob's estimates, a colposcopy required only 10 good instruments and 20 colposcopists in order to diagnose 1,000 women per day, a number impossible to achieve in a laboratory; in addition, Jakob claimed that the cost of large-scale colposcopic examinations was considerably cheaper than that of cytological exams; and, lastly, d) reliability was a highly contested issue. Jakob's results with cytological analysis were not promising: out of 8 preinvasive cancers detected by colposcopy, only 5 tested Pap positive. Colposcopy was considered a more efficient and economic method for detecting precancerous lesions in a systematic way.

Between 1934 and 1954, around 24,494 colposcopies were carried out at the Sardá Maternity Hospital, where 38 preinvasive carcinomas were detected. It was estimated that there was one preinvasive cancer for every 700 or 900 patients. This contrasted sharply 
with Pap rates, alleged to stand at 1:74. Not surprisingly, Jakob drew attention to the ever higher rate of cancer detection through cytology, as reported in the United States. He believed that "any large statistics that pushed this value below 700 should be questioned" (Jakob, 1958, p.60).

The importance of colposcopy loomed large for Argentinean gynecologists. The professionalization of its practice and the creation of national societies and international federations ensured the transferred technique a permanent status. In 1964, the Argentinean and American societies for colposcopy and cervical pathology were founded. In 1972, Argentina hosted the First World Congress for Cervical Pathology and Colposcopy in Mar del Plata; with four national societies in attendance, this event led to the creation of the International Federation of Cervical Pathology and Colposcopy. In the next section, I will consider the transfer of colposcopy and Pap tests into Brazil, starting with the gynecological service where the technique was first used and the interlinked networks where both techniques were disseminated. Finally, an overview of the process of appropriation experienced with both techniques will lead to an assessment of how the field of cancer diagnosis was transformed.

\section{Brazil}

The 1930s witnessed the growing specialization of gynecology as a branch separate from obstetrics, pressuring doctors to become specialists in only one of the disciplines that societies, congresses, and some teaching programs still maintained under one umbrella. The case of Brazil's main referent in gynecology in this period, Dr. Arnaldo de Moraes (1893-1961), is instructive. After graduating with a medical thesis in obstetrics in 1916, he initiated his professional career as a Lecturer in Obstetrics (1924) and later trained in the United States in organizing maternal and child assistance under a grant from the Rockefeller Foundation (1927). He also trained in obstetrics and gynecology in France, Germany, and Austria, as was the practice for any specialist who wanted to hold a place of note in the profession.

Early in the 1930s, however, he steered his teaching and clinical work sharply towards gynecology, wherehe becameinstrumental in the process of specialization that the discipline underwent in thefollowing decades. In 1931, he was appointed head of Clinical Gynecology at Rio de Janeiro's Fluminense School of Medicine (Faculdade Fluminense de Medicina), but it was his 1935 appointment as head of the newly created Gynecology Department at the University of Brazil (Universidade do Brasil) that earned him wide recognition as a leading expert in this field. Until then, gynecology was not taught as a regular course but formed part of the general surgery curriculum. This was both an advantage and a disadvantage in that Moraes had ample opportunity for developing the department's profile and teaching contents, while he likewise grappled with the lack of infrastructure and teaching facilities - for example, it was only in 1936 that teaching rooms were assigned at the university's teaching facility, Estácio de Sá Hospital.

At that time, Estácio de Sá Hospital had yet to play a significant role in organizing cancer care in Brazil. Dr. Mário Kroeff, Brazil's leading figure in the field of cancer, was 
calling for health authorities to create a cancer center. This finally came about when construction of a cancer institute at Estácio de Sá Hospital was approved in 1937. The Cancer Institute (Instituto do Câncer) was inaugurated the following year under the direction of its planner, Kroeff; it offered cancer diagnosis and treatment in all specialties and also provided electro-surgery, radiotherapy, and radium-therapy. According to Luiz A. Teixeira and Cristina Fonseca, towards the end of the 1930s, Kröeff's ambition was to enlarge the scope of the Institute from a local to a national facility (Teixeira and Fonseca, 2007, p.73). His prominent position in political and academic circles enabled him to secure the 1941 creation of a National Cancer Service (Serviço Nacional do Câncer, or SNC) as part of the Cancer Institute, with the aim of centralizing cancer policies across the country, with an emphasis on cancer research, epidemiology, diagnosis, prophylaxis, and treatment. However, in 1942, the Brazilian government turned Estácio de Sá Hospital into a facility for the military police, leaving the Cancer Institute to be housed in unsuitable accommodations (Teixeira and Fonseca, p. 74-77). That same year, Moraes moved the university's Gynecology Clinic to Moncorvo Filho Hospital, a children's hospital founded by prominent pediatrician Dr. Carlos Arthur Moncorvo Filho, where the clinic is still based today. From 1940 on, Moncorvo Filho Hospital depended on the National Children's Department (Departamento Nacional da Criança), becoming a leading institution in maternal and child care, specialties that constituted Moraes' first professional areas of medical practice.

The diversification of services at Moraes' clinic reflected the degree of specialization in gynecology back then, at a time when any policy on cancer in women would be subject to negotiation among experts. In this sense, the process of institutionalization proved fundamental. In 1947, Moraes transformed the clinic into the Gynecology Institute (GI), which combined clinical and research work on a range of gynecological ailments, providing room for consults in endocrinology and sterility, roentgen therapy services, a laboratory for embryology and experimental research, a discussion forum, and an archive.

More importantly, in January 1948, the Ambulatório Preventivo do Câncer da Mulher was created as a special outpatient clinic focused on the prevention and early diagnosis of women's cancer. "How can we draw patients to this outpatient clinic," Moraes asked, "where we have intentionally used the term 'prevention' of gynecological cancer, rather than using the term 'detection', as the Americans do?" (Moraes, 1950a, p. 247). Thenuanced use of words reveals the lack of consensus among gynecologists about what constituted precancerous lesions and what their detection actually meant: the detection or the prevention (avoidance) of cancer. In either case, I will argue that such controversies expanded the opportunities for making the diagnosis rather than the treatment of cervical cancer a distinctive area of intervention. In this context, the role of diagnostic tools was highly significant, as we will see next, with the reception of colposcopy and the Pap test.

\section{Colposcopy}

In a commemorative article on the arrival of colposcopy in Brazil, Moraes commented that he had learned about the instrument after reading a chapter by Hinselmann in the 
treatise Gynecology and obstetrics, published in English by the American Carl H. Davis in 1934. This raises the question of why colposcopy did not prosper at this time in the United States, since it has been argued that the "early descriptive terminology was in German and was not readily understood in English-speaking countries" (Ferris et al., 2004, p.4). This reminds us that, beyond the linguistic competence required for any translation work, deciding what to translate and which foreign texts to introduce in a scientific culture is contingent on more complex strategic decisions.

According to Moraes, he taught himself how to perform a colposcopy after purchasing two colposcopes from the Leitz Company, one for the outpatient ward at the university clinic and one for his private practice. He soon realized that a good command of the technique required specialized training, and so he assigned one of his assistants to learn the technique, probably in Buenos Aires with Jakob. However, it was another doctor, João Paulo Rieper, who trained with Hinselmann in Hamburg and became a specialist in the technique. He was appointed assistant at Moraes' university clinic in 1940. His medical thesis "Valor prático da colposcopia" (On the practical value of colposcopy, 1942) earned him instant recognition as a leading figure in the practice of colposcopy in Brazil. Rieper's appointment proved significant to the dissemination of colposcopy among gynecologists, as had been the case with Jakob in Argentina. For both men, it was their personalized training in Germany with the inventor of the technique that gave them distinctive expertise during the 1930s and 1940s. Hinselmann's disciples thus became the "mediators" in the process of transfer, a role that implied mediation between a manifested desire to receive (exemplified by department heads Ahumada in Argentina and Moraes in Brazil) and the degree of assimilation of foreign ideas and techniques.

As mentioned above, a second phase in the history of the transfer of colposcopy in South America took place in the 1950s and was precipitated by Hinselmann's travels to the region. Although it is unlikely that contacts were easy during Hinselmann's imprisonment between 1946 and 1949, he accepted an invitation by Moraes shortly after his release and arrived in Rio de Janeiro in December 1949 to give training courses in colposcopy at the GI. Hinselmann's demonstrations were widely attended by doctors from Rio, São Paulo, Belo Horizonte, Bahia, and Porto Alegre. A special issue of the Anais Brasileiros de Ginecologia honored his visit with the publication of a brief autobiography, four original articles, and extensive notes and discussions from his courses. Significantly, he lectured in English.

In his biography, Hinselmann briefly referred to the end of the Nazi regime, which led to his imprisonment. He stated uncompromisingly that,

My research and teaching activities were abruptly interrupted by the political un rest of Central Europe, despite being not interested, I was caught up and al most crushed by it. But my colleagues from Germany and abroad have hel ped me, above all the Brazilian Society of Gynecology, and, especially, its magnanimous president and very dear friend, Prof. Arnaldo Moraes (Hinselmann, 1950, p.210).

This gratitude to Brazilian gynecologists must indeed have been sincere for a man who was practicing colposcopic examinations in Hamburg, in post-Nazi Germany, "'for anyone' in a barn in my private grounds," to use his words (Hinselmann, 1952b, p. 988). In 1951, 
Hinselmann was invited by Dr. Clovis Salgado, director of the gynecology clinic at the University of Minas Gerais (UGM) in Belo Horizonte, to participate in a congress and later by Dr. Ahumada to offer training courses in Buenos Aires, as mentioned earlier (Hinselmann, 1952b, p. 988). On this occasion, Dr. Rocha recalled the German doctor's visit to Belo Horizonte as "decisive":

It was after his visit that we were able to equip the clinic with the new colposcope models, standard, and fluorescent, which greatly facilitated the acceptance and dissemination of the colposcopic method, given the great facility brought to its learning technique and the remarkable improvements introduced in the apparatus in Germany after the War (Rocha, 1955, p.221).

The dissemination of these new models was fundamental to Hinselmann, for he felt that the lack of familiarity with early versions of the colposcope was a real obstacle to acceptance of the technique. The perfection of the instrument's visual capabilities (magnification increased from 10x to 20x) and the use of a mercury lamp and fluorochromes to increase image contrast revealed new forms of malignant epithelium. Hinselmann drew attention to the observation of the atypical proliferation of blood vessels, which indicated increased metabolism of cancerous cells. In addition to communicating theseimprovements, Hinselmann convinced Brazilian gynecologists as to the importance of histological analysis as a fundamental part of colposcopy. Following biopsy, every suspected image was subject to a procedure he devised, involving the observation of at least one thousand serial sections per biopsy. Following a request from Moraes, Hinselmann sent two German pathologists, Gerhard Franz (1951) and Hans Limburg (1953), to organize the pathology laboratory at the $\mathrm{Gl}$ and to supervise and instruct pathologists in his histological technique.

Perhaps drawing on the gendered division of labor common in the Pap test laboratory, where female technicians read slices, Hinselmann thought that women technicians would offer an invaluable contribution to the practice of histological sections. He attempted to disseminate this practice in Brazil by sending two German female assistants to perform the serial sections at the pathology laboratory at Salgado's gynecology clinic at the UMG. By 1953, the UMG's laboratory of anatomo-pathology employed a woman technician, Licy Teixeira, who was responsible for serial section analyses from all gynecology clinics in the state of Minas Gerais. At the GI in Rio de Janeiro, two women doctors were credited for their professional achievements: Dr. Hildegard Stoltz specialized in colposcopy, while Dr. Clarice do Amaral Ferreira had prime responsibility for cytological examinations and in 1956 became founder of the Brazilian Cytology Society (Sociedade Brasileira de Citologia). Notably, they were medical doctors, not technicians, as was the practice with Pap tests at laboratories in the United States; furthermore, unlike Argentinean female gynecologists, the Brazilians held positions at prestigious clinics.

The thirtieth anniversary of colposcopy in 1955 was celebrated with a special edition of the Anais Brasileiros de Ginecologia. The issue gathered the work of the main referents of colposcopy at the time: Wespy (Switzerland), Ahumada and Jakob (Argentina), M estwedt (Germany), and Rocha, Moraes, Rieper, and Stoltz (Brazil). Two years later, Hinselmann embarked on his third and final visit to Brazil to receive the honorary degree of doctor 
honoris causa from the University of Brazil, which constitutesthehighest academic distinction awarded by a university. The occasion once again offered the German doctor the opportunity to convey further technical improvements, including his incursions with video colposcopy. Ahead of their Argentinean colleagues, the Brazilians made innovative inroads into the professionalization of what had become a new specialty, with the 1958 creation of the Brazilian Col poscopy Society (Sociedade Brasileira de Colposcopia). Although all these elements reflected the existence of a solid German-Brazilian bond in this period, Brazilian gynecologists responded flexibly yet not submissively to the reception of Hinselmann's technique, as the next section will demonstrate.

\section{Colpocytology}

Exfoliative cytology as a method of cancer diagnosis was introduced in Brazil by Dr. Antonio Vespasiano Ramos, who worked as an assistant at Moraes' university gynecology clinic. Following the procedures of Papanicolaou and Traut, as first published in 1941, Vespasiano Ramos presented his medical thesis just one year later, entitled "Novo método de diagnóstico precoce do câncer uterino" (New method of early diagnosis of uterine cancer), which gives us insight into the pervasiveness of the early diagnosis goal as it spread almost simultaneously throughout Western medical centers. Moraes lent great importance to cytology, as evinced by his visit to Papanicolaou in New York in 1950 and by his assigning his assistants, including Dr. Dig Gebara, to train in New York with the inventor of the test. According to Rieper, Gebara became the leading figure in cytology in Brazil, training numerous cytologists and doctors from leading institutes on the technique. After his death, a woman - Dr. Clarice do Amaral Ferreira - took the lead and became "the best qualified in cytology in Brazil" (Rieper, 1959, p.270).

In terms of the transfer of diagnostic techniques, the early inception of exfoliative cytology at the GI led to more significant developments. As Henk Te Velde has perceptively noted in the transfer of political practices, "The most novel contributions could be expected from analysis of the agents of transfer, and especially of the simultaneous development of the international communication channels and the transfer itself and of the process of adaptation and 'translation'" (Te Velde, 2005, p.211).

These "novel contributions" can also be observed here. One of them was creation of a new term - colpocitologia (colpocytology) - coined by Moraes, one of the main agents in the process of transfer analyzed in these pages. Colpocytology referred to the practice and study of vaginal exfoliative cytology and became synonymous with the Pap test. It spread quickly to (Spanish-speaking) Latin America and is widely used today. Undoubtedly, the main original contribution that the transfer of diagnostic tools offered in this period was the systematic and simultaneous practice of colposcopy and the Pap test at the outpatient clinic known as the Ambulatório Preventivo do Câncer da Mulher. From January 1948, when the outpatient clinic opened to the public, until March 1950, the first 1,000 cases were reported with the following results: Out of 921 colposcopic examinations, 39 cases presented cancerous lesions; 11, "suspicious tissue changes"; and 24, "precursor tissue." Out of 855 Pap tests, 38 cases showed "strong atypia" while 59 cases showed "discrete 
atypia." Moraes concluded that "colposcopy, colpocytology, and histopathological examination have their own values and only the simultaneous use of the three provides a satisfactory and reasonably safe result" (Moraes, 1950b, p.435; emphasis added). The observed increase in diagnosed cases resulting from the combination of both methods is nevertheless revealing: 175 detected cases of precursor stages of cancer. "The number seems an exaggeration," Moraes observed. "In fact, only 73 cases were definitely labeled as malign neoplasias" (Moraes, 1950a, p.249).

Aware of the strength that the simultaneous use of these diagnostic methods meant for the international prestige of Brazilian gynecology, Moraes sought to introduce further innovations in the area of cancer diagnosis. In 1951, together with one of his assistants, Dr. Nisio M. Fonseca, he published an article on a study that Fonseca was conducting on the detection of cervical cancer with the use of a phase-contrast microscope. The aim of the research was to conduct a comparative study between the use of this new German technique and the Papanicolaou test. What is instructive in this case is the scientific, medical network that the GI director had built up over these years. Fonseca had trained in pathological anatomy Franz, who had been sent by Hinselmann to organize the laboratory at the GI. After Moraes received the donation of a phase-contrast microscope, he commissioned Fonseca to train in cytology at the Institute of Biological Investigations (Instituto de Investigaciones Biológicas) in Montevideo, an institute created by the Rockefeller Foundation, which also awarded Fonseca a fellowship. Moraes also commissioned Dr. Orlando Baiocchi, from the laboratory of experimental gynecology, to study the diagnosis of exo-cervical cancer by glycogen analysis in Paris and to study pathological anatomy with the renowned specialist Dr. Jean Leroux-Robert. Crucially, it was this style of scientific work, which combined and adapted available foreign methods and technologies, that earned the GI international recognition for its work.

\section{Conclusions}

Throughout this paper, I have pointed to the importance of the concept of transfer in analyzing the migration of medical ideas across national borders. The history of gynecological cancer is illustrative at several levels. First, the transfer of diagnostic tools (col poscopy and Pap test) in Argentina and Brazil illustrate how foreign medical knowledge and practice hel ped to shape national medicine. Second, it indicates that most developments in cancer knowledge, specifically in the diagnosis of gynecological cancer, cannot be understood without parallel developments in several countries. Third, the process of transfer of medical ideas and technologies from Germany and the United States to South America and later from South America to Europe and the United States contributed significantly to the naturalization of the notion of early detection in cancer care.

In addition, the way in which the transfer of medical ideas took place at this time is very instructive. In the arbitrary distribution of the "geography of knowledge," it was less a history from center to periphery and more a process where the "peripheral" centers managed to articulate some central functions. Arguably, South American gynecological centers dealt with the "excesses" of the international scientific community by offering a 
more balanced assessment of its so-called achievements (promotion of Pap tests in the United States) and neglection. (Hinselmann's colposcopy). Crucially, in times of perceived competition among the main Western scientific models (France, United States, and Germany) in an effort to hold sway over Latin America, South American centers and scientists seem to have handled their medical borrowings more opportunistically. As we have seen, the reception, implementation, and adoption of diagnostic tools was not a passive process. The strength of Argentinean and, more clearly, Brazilian gynecology was precisely the combined used of both diagnostic tools.

Some of the consequences inherent to the migration of colposcopy and the Pap test have been highlighted in this paper. On the one hand, diagnostic methods have to negotiate and compensate for each others' fallibility. In this case, three methods were considered to be needed, giving rise to a new type of "cumulative confidence" based on the combined use of colposcopy, the Pap test, and biopsy. On the other hand, this meant an increase in the number of cases diagnosed. In the Brazilian case, for example, during 1943-1947, when systematic colposcopy was not used, 7 cases of precancerous lesions (stage 0) were diagnosed in 4,000 women. During 1948-1955, when systematic colposcopy and cytology were employed, 40 cases were diagnosed in 7,000 women (Stoltz, 1955, p. 214), thus elevating the ratio from 1:571 to 1:175.

The way gynecologists treated and dealt with these borderline lesions lies outside the scope of this paper; however, regardless of their preferred therapeutic treatment, the diagnosis of precancerous lesions would have confronted them with the same dilemma posed some decades later by pathologist Robert Hutter: "Is cured early cancer truly cancer?"

\begin{abstract}
* Research for this paper was generously funded by a Research Fellowship awarded by the Wellcome Trust (WT082964). Early versions of the paper were discussed at the cancer workshops held in Maison Française d'Oxford, Oxford University, February 2009, and in CERMES and the Institut National du Cancer, Paris, April 2009. This work has benefited from the generous feedback provided by Ilana Löwy, Viviane Quirke, John Pickstone, Patrice Pinell, and the participants of both workshops. I am also indebted to the journal's editor, Jaime Benchimol, for his suggestions and to Anna von Villiez for helping with the German translations.
\end{abstract}

\title{
REFERENCES
}

AHUMADA, Juan Carlos.

Conferencia inaugural de la cátedra de clínica ginecológica. La Prensa Médica Argentina, Buenos Aires,v.22, n.21, p.986-995. 1935.

BENCHIMOL, Jaime; SÁ, Magali (Ed.). Adolpho Lutz, obra completa. Rio de Janerio: Editora Fiocruz. 2004-2005-2006-2007. 3v.

BRYDER, Linda.

Debates about cervical screening: an historical overview. Journal of Epidemiology and Community Health, London, v.62, n.4, p.284-287. 2008.

BURGHARDT, Erich; PICKEL, Hellmuth; GIRARDI, Frank.
Colposcopy, cervical pathology: textbook and atlas. $3^{\text {rd }}$ Edition. Thieme. 1998.

CARVALHO, Alexandre Octávio Ribeiro de. O Instituto Nacional de Câncer e sua memória: uma contribuição ao estudo da invenção da cancerologia no Brasil. Dissertação (Mestrado Profissionalizante) - Programa de Pósgraduação em História Política e Bens Culturais, Mestrado Profissionalizante em Bens Culturais e Projetos Sociais, Fundação Getulio Vargas, Rio de Janeiro. 2006.

CASPER, Mónica; CLARKE, Adele. Making the Pap smear into the 'right tool' for 
the job: cervical cancer screening in the USA, circa 1940-95. Social Studies of Science, London, v. 28, n.2, p.255-290. 1998.

CERUTTI, Nazario.

La colposcopía en las lesiones del cuello uterino. Revista de la Asociación Médica Argentina, Buenos Aires, v.16, n.729, p.180-182. 1952.

CHARLE, Christophe; SCHRIEWER, Jurgen; WAGNER, Peter.

Editors Preface. In: Charle, Christophe;

Schriewer, Jürgen; Wgner, Peter (Ed.).

Transnational Intellectual Networks: forms of academic knowledge and the search for cultural identities. Frankfurt: Campus Verlag. p.9-14. 2004.

CUETO, Marcos.

Missionaries of science: the Rockefeller Foundation and Latin America. Bloomington: Indiana University Press. 1994.

DASTON, Lorraine; GALISON, Peter. Objectivity. New York: Zone Books. 2007.

DE LA VEGA, Juan Carlos.

El primer congreso de obstetricia y ginecología en Argentina. Notas y comentarios. Revista Médica del Rosario, v.21, n.8, p.489-493. 1931.

ERASO, Yolanda.

A burden to the state: the reception of the German 'Active Therapy' in an Argentinian colony-asylum in the 1920s and 1930s. In: Ernst, Waltraud; Mueller, Thomas (Ed.). Transnational psychiatries: social and cultural histories of psychiatry in comparative perspective, c. 1800-2000. (Forthcoming) Cambridge: Scholars Publishing. 2010.

ERASO, Yolanda.

Accustoming the eye to see what is observed: politics, specialisms and tensions in the use of diagnostic methods for the detection of cervical cancer in Argentina. In: Workshop How to deal with cancer? Research, innovation and politics, 2009, Oxford. Proceedings... Oxford: Maison Françasie d' Oxford; Oxford University. 2009.

FERRIS, Daron et al.

Modern colposcopy: textbook and atlas. United States: American Society for Colposcopy \& Cervical Pathology. Kendall Hunt. 2004.

GANDOLFO HERRERA, Roberto.

Diagnóstico precoz del cáncer en la mujer. Revista Médica Latino-Americana,|v.19, n.224, p.843-868. 1934.

GIMÉNEZ, José.

Formas clínicas, diagnóstico y tratamiento del cáncer de útero. Revista Argentina de Obstetricia y Ginecología, v.10, n.1, p.89-91. 1926.
HAUPT, H.G; KOCKA, J.

Comparative history: methods, aims, problems. In: Cohen, D; O'Connor, M. (Ed.). Comparison and history: Europe in Cross-National Perspective. New York: Routledge. p.23-39. 2004.

HINSELMANN, Hans.

Diagnóstico de los estados precursores del carcinoma de cuello uterino. Revista Médica de Córdoba, Córdoba, v.40, n.1 p.12-15. 1952a.

HINSELMANN, Hans.

4 Monate in Südamerika. Münchener

Medizinische Wochenschrift, Munchen, v.94, n.19, p.987-990. 1952b.

HINSELMANN, Hans.

Prof. Dr Hans Hinselmann (Hamburgo). Anais

Brasileiros de Ginecologia, Rio de Janeiro, v.29,

n.3, p.207-210. 1950.

HUTTER, Robert.

Is cured early cancer truly cancer? CA: A Cancer Journal for Clinicians, New York, v.32, n.1, p. 2-9. 1982.

JAKOB, Alfredo.

La profilaxis del cáncer de cuello: el período de latencia. El Día Médico, n.52, p.51-52. 1939.

JAKOB, Alfredo; ESCALANTE, Dardo.

El cáncer preinvasor del cuello uterino: su diagnóstico precoz, histología y tratamiento. Buenos Aires: Editorial Bibliográfica Argentina. 1958.

LERNER, Barron.

The breast cancer wars: hope, fear, and the pursuit of a cure in twentieth-century America. New York: Oxford University Press. 2001.

LÖWY, Ilana.

Preventive strikes: women, precancer and prophylactic surgery. Baltimore: The Johns Hopkins University Press. 2010.

LÖWY, Ilana.

The Right Tool For the job, But what is the job? In: Workshop How to deal with cancer? Research, innovation and politics, 2009, Oxford. Proceedings... Oxford: Maison Françasie d' Oxford; Oxford University. 2009.

MORAES, Arnaldo de.

Práctica do diagnóstico precoce do câncer ginecológico. Anais Brasileiros de Ginecologia, Rio de Janeiro, v.29, n.3, p. 247-250. 1950a.

MORAES, Arnaldo de.

Sociedade Brasileira de ginecologia. Anais Brasileiros de Ginecologia, Rio de Janeiro, v.29, n.5, p.432-436. 1950b. 
MoscuCCl, Ornella.

Gender and cancer in Britain, 1860-1910.

American Journal of Public Health, Boston, v.95, n.8, p.1312-1321. 2005.

PROCTOR, Robert.

The Nazi war on cancer. Princeton University Press. 2000.

REGGIANI, Andrés.

Medicina y Kulturpolitik en la era del Nacional socialismo: la Academia Médica Germano-Ibero-Americana (1936-1939). In: Carreras, Sandra. Der Nationalsozialismus und Lateinamerika: institutionen - repräsentationen - wissenskonstrukte I. Berlin. p. 57-74. 2005.

Disponível em: http://www.iai.spk-berlin.de/ fileadmin/dokumentenbibliothek/lbero-Online/ 003 1.pdf Acesso em: 25 maio 2009.

ROCHA, Alberto $\mathrm{H}$.

A Colposcopia na clinica ginecológica da Facultade de Medicina da Universidade de Minas Gerais (1941-1955). Anais Brasileiros de Ginecologia, Rio de Janeiro, v.40, n.3, p.219-226. 1955.

SÁ, Magali Romero et al.

Medicine, science, and power: relations between France, Germany, and Brazil during 1919-1942. História, Ciências, Saúde - Manguinhos, Rio de Janeiro, v.16, n.1, p.247-261. 2009.

SALVATORE, Ricardo (comp.).

Los lugares del sabe: contextos locales y redes transnacionales en la formación de conocimiento moderno. Rosario: Beatriz Viterbo. 2007.

\section{SCHTIRBU, Isaac.}

La colpocitología en el diagnóstico de cáncer uterino. Obstetricia y Ginecología LatinoAmericanas, Buenos Aires, v.6, n.5, p.201-210. 1948.

STOLTZ, Hildegard.

Aspectos colposcópicos do carcinoma grao 0 . Anais Brasileiros de Ginecologia, Rio de Janeiro, v.40, n.3, p.213-216. 1955.

TEIXEIRA, Luiz Antonio; FONSECA, Cristina Oliveira.

From an unknown disease to a public health problem: INCA and cancer control in Brazil. Brasília: Ministério da Saúde. 2007.

TE VELDE, Henk.

Political transfer: an introduction. (special issue: political transfer). European Review of History, v.12, n.2, p.205-221. 2005.

WERNER, Michael; ZIMMERMANN, Bénédicte. Beyond comparison: histoire croisée and the challenge of reflexivity. History and Theory, Middletown, v.45, n.1, p.30-50. 2006.

WERNER, Michael; ZIMMERMANN, Bénédicte (Ed.).

De la comparaison à I'histoire croisée. Paris: Seuil. 2004.

WILLIAMS, John.

Cancer of the uterus: being the Harveian lectures for 1886. London: HK Lewis. 1888.

\section{u u UUU}

